\title{
To be sought first: The grandest of themes
}

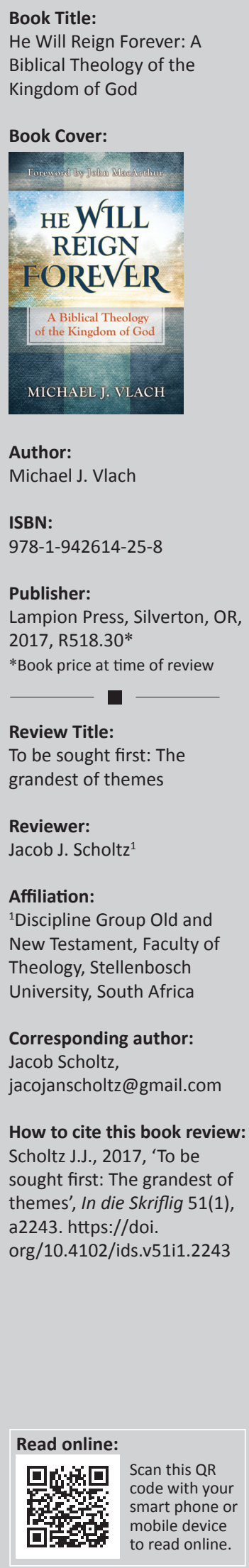

The goal of He Will Reign Forever: A Biblical Theology of the Kingdom of God is 'to present a comprehensive biblical theology of the kingdom of God from a new creationist perspective' (p. 11). This perspective holds (inter alia) that Jesus Christ will restore all things through His two comings to earth (pp. 12, 23); that individuals, Israel, the Church and the nations are all important in God's kingdom (pp. 14-15, 45-50, 521); and that the coming new earth will be this present earth purged and restored (pp. 14, 509-515). After introducing the kingdom programme (Part 1), Vlach traces the kingdom theme through the Old Testament (Part 2) and the New Testament (Part 3), before concluding with an examination of theological issues (Part 4). A bibliography, author index, Scripture index and subject index are provided.

In Part 1 (chs. 1-3), the author identifies the Creation (Gn 1-2), Fall (Gn 3), Promise (Gn 3:15-Ml), Redemption (Gospels-Epistles) and Restoration (Revelation) as five major developments in God's kingdom programme (pp. 22-23). The kingdom involves not only spiritual and material elements, but also social, political and geographical aspects (pp. 11-12, 563). Vlach asserts that the elements of a ruler, a realm and active rulership are all needed for a kingdom, but at times 'one of these three elements can be singled out and designated as "kingdom"' (p. 29). For example, Jesus goes to a distant country to receive a kingdom, and yet his actual kingdom reign awaits his return (p. 29; Lk 19:11-27; cf. also Rv 1:6 with 5:10). By God's sovereign design, the timing of the kingdom's establishment on earth can be influenced by Israel's acceptance of the Messiah (pp. 17, 50-51; cf. 97-100, 374-379). Israel is not an end, but is rather a means to universal blessings; what is 'true for the particular (Israel and Israel's land) will also be true for the universal (other nations and their lands)' (p. 17; cf. 81-85).

In Part 2 (chs. 4-14), the unconditional covenants are viewed as the 'means through which God's kingdom program is manifested' (p. 96). Israel 'became a nation and a kingdom at Sinai' (p. 94) and had to obey the conditional Mosaic Covenant to experience the spiritual and physical blessings of the unconditional Abrahamic Covenant (pp. 96-97). The kingdom flourished under David and Solomon, but ended when God's glory left the temple (pp. 194-196). However, God promised by means of the Law (Lv 26:40-45; Dt 30:1-10) and the Prophets (Is 49:3-6; Jer 3:11-18; Zch 12:1-10), that if Israel repented, the nation would be restored to the land and experience spiritual and physical prosperity in the kingdom (p. 100). What the Mosaic Covenant could not do, the New Covenant would enable Israel (and others) to do: to obey God (p. 187).

In Part 3 (chs. 15-34), Vlach explains that the kingdom which the forerunner and Jesus proclaimed was 'in continuity with the OT kingdom expectation' (p. 269). He argues that 'at hand' means that the kingdom was imminent (pp. 272-275), that Jesus' miracles were 'tastes and previews of the coming kingdom' (p. 295), but that Israel had to repent and become spiritually qualified for its coming (pp. 275, 326). Last-mentioned contingency was not met (ch. 20). The necessity of two comings of the Messiah becomes clear and the kingdom will be 'near' during the future tribulation period (p. 323). The kingdom programme outlined in Matthew 13 'is related to the present age in regard to the message of the kingdom and the growth of kingdom citizens', but the kingdom reign itself has not been established in this age (p. 332). Vlach concludes Part 3 by discussing numerous New Testament texts to indicate that Christ will rule the kingdom in the future.

In Part 4 (chs. 35-39), the author argues that before the kingdom of the Son will merge with the eternal kingdom of the Father, the Last Adam must successfully rule from and over the realm (earth) where the first Adam failed (chs. 36-37; cf. also p. 18). A nuanced proposal is made regarding fulfilment and the Davidic Covenant (ch. 38).

When interacting with the ideas of various scholars, Vlach remains courteous and balanced. In agreement with many theologians, Vlach views the kingdom of God as the 'grand central theme of Scripture that encompasses all other biblical themes' (p. 21). The author emphasizes that the

Copyright: (C 2017. The Authors. Licensee: AOSIS. This work is licensed under the Creative Commons Attribution License. 
'NT continues the OT storyline and affirms literal fulfilment of the OT promises and covenants in all their dimensions through two comings of Jesus' (p. 38). He rejects the view that the 'kingdom message of the OT authors is reinterpreted, redefined and spiritualized by Jesus and the NT writers' (p. 40; cf. also 266, 277, 312). There is no 'reality shift from OT expectation to NT fulfillment' (pp. 16-17). Forms of Platonism are strongly rejected (pp. 16, 46, 563-567). The author avoids the stances of some of his predecessors: there is 'present applicability' of the Sermon of the Mount (p. 302) and a 'mystery form' of the kingdom is not preferred (p. 325). While aspects of the New and Davidic Covenants have been fulfilled, he does not support an exclusively spiritual or already/not yet view of the kingdom in this age. Vlach (p. 571) writes that 'Jesus fulfills the promise of a Davidic King who is at the right hand of God (already), but His messianic kingdom reign from David's throne on earth is future (not yet).' While some will disagree with his conclusions - Vlach highlights 11 beliefs that influence his understanding of the kingdom (pp. 33-51) - theologians of various convictions will simply have to interact with this superb book.

This reviewer is not convinced that the kingdom was reoffered in Acts 3 to the same generation that had a short while ago rejected the Messiah (pp. 413-421; cf. 369) and I understand the keys of the kingdom given to Peter a bit differently (pp. 337-338). However, I especially appreciated the discussions about the mysteries of the kingdom of Matthew 13, fulfilment and the Davidic Covenant and Vlach's contribution to the doctrine of the nations.

The strength of this work is the scope and sheer comprehensiveness of its biblical treatment of the kingdom of God. The presentation is sensible and every believer can benefit from it practically. He Will Reign Forever: A Biblical Theology of the Kingdom of God is an excellent book and I recommend it highly. 